\title{
CRASSULA GENUS PLANTS RESPONSE TO TEMPERATURE STRESS DEPENDS ON ANATOMICAL STRUCTURE AND ANTIOXIDANT SYSTEM
}

\author{
N. V. NUZHYNA ${ }^{\bowtie}$, M. M. GAIDARZHY, A. V. HOLUBENKO \\ ESC "Institute of Biology and Medicine", \\ Taras Shevchenko National University of Kyiv, Ukraine; \\ e-mail: nuzhynan@gmail.com
}

Received: 09 October 2020; Accepted: 15 May 2020

\begin{abstract}
Plant adaptation to climate conditions of certain territories has emerged within the course of evolution, shows at all organizational levels from morphological-anatomical to biochemical and is embedded into the plant genes. Survival of plants in such conditions as rapid temperature drops and rises in the range of $20{ }^{\circ} \mathrm{C}$ or more depends on their biochemical defense system's ability to quickly respond to such stress, as well as on the plant's structural features. Therefore, our goal was to analyze changes of biochemical parameters under conditions of abrupt hyperthermia in four species of Crassula Linne genus and to establish the connection between their anatomical and morphological features and the peculiarities of the biochemical reactions. Plants of Crassula brevifolia Harvey, Crassula lanuliginosa Harvey, Crassula muscosa Linne and Crassula perfoliata var. minor (Haworth) G.D. Rowley species were held in air thermostats at $40^{\circ} \mathrm{C}$ and $50{ }^{\circ} \mathrm{C}$ for $3 \mathrm{~h}$, the control temperature being $26^{\circ} \mathrm{C}$. Stress response was analyzed by malondialdehyde content, superoxide dismutase and peroxidase activity and pigments content. Additionally, anatomical structure of the leaves was investigated. Antioxidant response to short-term high temperature varied in different species of the Crassula genus by its directionality and intensity, and depended on the anatomical features of the plant. The additional protective mechanisms were involved in the least heat-resistant plants, such as increased carotenoids and flavonoids contents. More powerful SOD and peroxidase activities under rapid heating in plants with more effective protection at the anatomical level were showed.
\end{abstract}

Ke y w o r d s: hyperthermia, peroxidase, superoxide dismutase, pigments, Crassula genus.

$\mathrm{U}$ nder climate change, survival of plants depends on a range of their adaptive measures. The combination of structural adaptive features (anatomical, morphological) with biochemical reaction to abrupt temperature changes is especially important. Development and interaction of these stress defense systems define the general strategy of the plant survival. Researchers separate two different mechanisms of plant reaction to temperature stress. The first one is the avoidance mechanism, which includes an anatomical, morphological and/or physiological level of protection. The avoidance mechanism is closely related to the second type - biochemical protection. It includes synthesis of osmoprotectors, antioxidants, phytohormones, change of protein activity and regulation of ionic transport [1]. High temperature stress may cause overproduction of reactive oxygen species (ROS), which can cause oxidative stress. To counter it, ROS have to be neutralized by detoxifying enzymes, with the first link being established by superoxide dismutase (SOD), catalase and peroxidases, and also protection of cell components via synthesis of metabolites with low molecular mass and secondary metabolites [1-5]. Objects for investigating the mechanisms of resistance to heat, drought, and cold were, fist and foremost, agricultural plants (corn, wheat, soy etc), because their resilience affects yields [6-8] or common model plants such as arabidopsis [9]. However, one of the crucial factors which ensure the survival of rare species is resistance to high ambient temperature and to rapid change of tempera-

(C) 2020 Nuzhyna N. V. et al. This is an open-access article distributed under the terms of the Creative Commons Attribution License, which permits unrestricted use, distribution, and reproduction in any medium, provided the original author and source are credited. 
ture. Plants growing on water-deficient territories can be model objects for investigation of this paper. Such plants, among others, are species of Crassula Linne, family Crassulaceae De Candolle, spread in Africa, Madagascar and Arabian peninsula [10]. All species of the Crassula genus, of which there are almost 200, are leaf or root succulents and vary in morphological and anatomical structure. Different species have different variations of structural features aimed to protect them from intensive exposure to sunlight, drought and high temperature, such as: specific disposition of leaves (spiral or double-row), which facilitates self-shading and conservation of moisture, different volume of aquiferous tissue, large numbers of trichomes or wax coating on the leaf surface, widened epidermal cells, able to store water etc. The wide spectrum of adaptive features of the Crassula genus might indicate different response to high temperature for different species, especially to rapid changes in temperature. For example, it has not yet been established how SOD activity correlates with plant adaptability to extreme conditions, which was researched for, among others, plants of Crassulaceae genus [11]. In addition, some other representatives of this family don't show any change in content of such osmoprotectors as prolin and sugars under hyperthermia [12, 13]. The assumption of high specificity of plant reaction to temperature stress is partially confirmed, because, according to latest literature data and the results of our previous studies, conducted on representatives of such families as Asphodelaceae, Cactaceae, Rosaceae, hyperthermia may cause multi-directional reactions on biochemical level in plants with different anatomical features [14-17]. Thus, the purpose of our work was to establish the connection between anatomical and morphological features of certain Crassula species with peculiarities of biochemical reactions to abrupt temperature increase which are a complex characteristic of resistance to hyperthermia.

\section{Materials and Methods}

One-year-old representatives of 4 species of Crassula genus were used in the experiment, namely - C. brevifolia Harvey, C. lanuliginosa Harvey, C. muscosa Linne i C. perfoliata var. minor (Haworth) G. D. Rowley [10, 18], which were grown in the greenhouse of O. V. Fomin Botanical Garden, Taras Shevchenko National University of Kyiv. The investigated species are included to the Red List of plants of South Africa and have the LC status [19].
The species are close by their geographical origin but differ in growth conditions and morphological structure (Table 1) [18].

Plants were grown at $25-26^{\circ} \mathrm{C}$, under $15,000 \mathrm{~lm}$ light and $30-80 \%$ humidity. Medial leaf parts of the plants were used for anatomical studies. Research was conducted in the second decade of May with the nonadapted to high temperature plants. The control group of plants was analyzed without additional temperature influence. The investigated plants together with the pots they had grown in were heated in an air thermostat at $40^{\circ} \mathrm{C}$ and $50^{\circ} \mathrm{C}$ during $3 \mathrm{~h}$, the control temperature being $26{ }^{\circ} \mathrm{C}$. Biochemical studies were conducted using an SF-2000 spectrophotometer.

Anatomical slices of the leaves were created by fixing the latter in an FAA solution and cast in gelatin by standard technique [20]. Lateral sections 15$20 \mu \mathrm{m}$ thick were made using a freezing microtome. The sections were dyed with safranin (as a stain for lignin such as in cell wall or xylem), sudan (which efficiently stained lipids) and I2-KI (for the visualization of starch granules) during 5 minutes on every dye, washing with distilled water after each one [20]. To study the epidermal structures, maceration of leaves was performed. Leaf blade epidermis was described by methods by Fatemeh Zarinkamar [21]. Microscopic measurements were taken using XSP146TR microscope and Image J software.

Lipid peroxidation was determined by malondialdehyde (MDA) content, determined from a color reaction with thiobarbituric acid, based on formation of tinted trimethine complex in acidic medium, with a characteristic absorption spectrum, with maximum at $\lambda=533 \mathrm{~nm}$. MDA amount was expressed as $\mu \mathrm{mol} / \mathrm{g}$ of fresh weight [22].

Superoxide dismutase (SOD) activity was determined by a method based on the SOD ability to compete against nitroblue tetrazolium for superoxide radicals coming from photooxidation of riboflavin at $\lambda=560 \mathrm{~nm}$ [23]. SOD activity was expressed as relative activity units per mg of protein. Protein content was evaluated according to Warburg $\mathrm{O}$. and Christian W. [24], at $\lambda=280$ and $\lambda=260 \mathrm{~nm}$ and expressed in $\mathrm{mg} / \mathrm{g}$ of fresh weight.

Peroxidase activity was determined by speed of benzidine oxidation reaction up to formation of the blue product of its oxidation in presence of $\mathrm{H}_{2} \mathrm{O}_{2}$ and peroxidase at $\lambda=590 \mathrm{~nm}$. Peroxidase activity was expressed as relative activity units per mg of protein [25].

Total flavonoid content percentage was expressed as rutin and absolutely dry substance deter- 
Ta b le 1. Morphological features of 4 species of Crassula genus

\begin{tabular}{|l|l|l|}
\hline \multicolumn{1}{|c|}{ Species } & \multicolumn{1}{|c|}{$\begin{array}{c}\text { Growth conditions } \\
\text { and location }\end{array}$} & \multicolumn{1}{c|}{ Morphological features } \\
\hline Crassula brevifolia & $\begin{array}{l}\text { South Africa-provinces } \\
\text { of Northern Cape, } \\
\text { Western Cape, among } \\
\text { the rocks }\end{array}$ & $\begin{array}{l}\text { Shrub, up to 50 cm high, leaves are wide, egg-like, 10- } \\
16 \text { mm long and 7-12 mm wide, have a red stripe on the } \\
\text { edge. Leaf configuration is double-row. Leaf surface is } \\
\text { light green with well-defined convex aquiferous cells. }\end{array}$ \\
\hline Crassula lanuliginosa & $\begin{array}{l}\text { South Africa - province } \\
\text { of Eastern Cape, on the } \\
\text { rocks among cereals }\end{array}$ & $\begin{array}{l}\text { Herbaceous plant with crawling forked stems. Leaf } \\
\text { configuration is double-row. Leaves are grayish green } \\
\text { with trichomes, narrow egg-shaped, sharpened in the } \\
\text { apical part, 8-15 mm long and 5-6 mm wide and thick. }\end{array}$ \\
\hline Crassula muscosa & $\begin{array}{l}\text { Southern Namibia, } \\
\text { South Africa (Northern } \\
\text { Cape, Western Cape, } \\
\text { Eastern Cape), among } \\
\text { the rocks }\end{array}$ & $\begin{array}{l}\text { Herbaceous plant with forked orthotropic stems up to 25 } \\
\text { cm in length. Leaves grow in a spiral, are closely stuck } \\
\text { together, bright green in color, in shape of elongated } \\
\text { triangles. They are up to 3 mm long and 2 mm wide and } \\
\text { thick in the lower part. }\end{array}$ \\
\hline $\begin{array}{l}\text { Crassula perfoliata } \\
\text { var. minor }\end{array}$ & $\begin{array}{l}\text { South Africa - province } \\
\text { of Eastern Cape, in dry } \\
\text { river valleys }\end{array}$ & $\begin{array}{l}\text { Shrub, up to 15 cm high, forked at the base of the } \\
\text { stem. Spiral leaf allocation. Leaves are in the shape of } \\
\text { elongated triangles, sharp in the apical part, slightly } \\
\text { curved, grayish blue in color, 50 mm long, up to 15 mm } \\
\text { wide and 6 mm thick. }\end{array}$ \\
\hline
\end{tabular}

mined as described by Payum T. et al. with slight modification [26] at $\lambda=410 \mathrm{~nm}$.

Pigments were extracted from plant material with $80 \%$ acetone and were determined at $\lambda=663$, 646, $470 \mathrm{~nm}$ in terms of dry weight [27].

The data were analyzed by Prism Graphpad 6. The values for different groups were compared by ANOVA followed by Tukey's multiply comparison test. A two-way analysis of variance (ANOVA) followed by a Bonferroni test was used when two factors were varied: temperatures $\left(26,40\right.$ or $\left.50^{\circ} \mathrm{C}\right)$ and species.

\section{Results and Discussion}

Anatomical studies. Representatives of Crassula genus generally have similar leaf anatomical structure [28]. Leaves of the studied species are covered in a single-layer epidermis with thickened cuticle. Adaxial and abaxial epidermis thickness wasn't reliably determined as different, but a certain tendency of thickened bottom epidermis is observed (Table 2). For the studied species of Crassula genus, anisocytic stomata apparatus is typical. The vascular conductive system is very underdeveloped, the mesophile is represented by water-storing tissue with large amount of inclusions in idioblasts. Staining with iodide and sudan did not reveal starch grains and lipid inclusions, respectively. Elements of mechanical tissue are almost non-existent.

Among the studied species, some differences in anatomical structure were found. Namely, C. muscosa leaf epidermis has no trichomes, the epidermis cells have straight, rounded shapes and square or elongated projections (Fig. 1, A, B). The stomata on both sides are evenly distributed and are the biggest among the studied species (Table 2). Leaf thickness of $C$. muscosa is the smallest.

Leaf surface of C. lanuliginosa on both sides is covered with single-cell, non-glandular trichomes $355 \pm 59 \mu \mathrm{m}$ long (Fig. 2, A, B). On both sides of the leaf, epidermal cells with flattened surface projection and curly shapes are prevalent.

Epidermal cells are significantly larger for C. lanuliginosa and C. muscosa compared to the other two species (Table 2).

C. brevifolia has the thickest leaf, but, however, has not the thickest epidermis. Epidermal wall thickness for this species is similar to that of $C$. muscosa and $C$. lanuliginosa (Table 2), but for $C$. brevifolia the outside cell wall is almost completely lignified, which indicates the xerophytism of the species. No trichomes are present on the surface, epidermis cells are linear and rounded with flattened projections on both sides (Fig. 3, $A, B$ ). 
Ta ble 2. Morphometric parameters of Crassula genus leaves

\begin{tabular}{l|c|c|c|c}
\hline \multicolumn{1}{c|}{ Parameter } & C. muscosa & C. lanuliginosa & C. brevifolia & $\begin{array}{c}\text { C.perfoliata } \\
\text { var.minor }\end{array}$ \\
\hline $\mathrm{H}$ leaf, $\mu \mathrm{m}$ & $714 \pm 102^{\mathrm{d}}$ & $2057 \pm 105^{\mathrm{c}}$ & $3909 \pm 103^{\mathrm{a}}$ & $3531 \pm 122^{\mathrm{b}}$ \\
$\mathrm{H}$ ad, $\mu \mathrm{m}$ & $31.42 \pm 2.86^{\mathrm{b}}$ & $31.65 \pm 4.17^{\mathrm{b}}$ & $33.41 \pm 7.79^{\mathrm{b}}$ & $42,05 \pm 6.36^{\mathrm{a}}$ \\
$\mathrm{H}$ ad k, $\mu \mathrm{m}$ & $8.04 \pm 1.68^{\mathrm{a}}$ & $7.59 \pm 3.38^{\mathrm{a}}$ & $7.91 \pm 1.90^{\mathrm{a}}$ & $6.87 \pm 1.88^{\mathrm{a}}$ \\
$\mathrm{H} \mathrm{ab}, \mu \mathrm{m}$ & $31.41 \pm 4.71^{\mathrm{b}}$ & $34.59 \pm 4.96^{\mathrm{b}}$ & $28.37 \pm 4.61^{\mathrm{b}}$ & $46.89 \pm 8.4^{\mathrm{a}}$ \\
$\mathrm{H} \mathrm{ab} \mathrm{k}, \mu \mathrm{m}$ & $8.13 \pm 2.27^{\mathrm{a}}$ & $9.32 \pm 2.81^{\mathrm{a}}$ & $9.23 \pm 1.87^{\mathrm{a}}$ & $7.68 \pm 2.48^{\mathrm{a}}$ \\
$\mathrm{L} \mathrm{ad} \mathrm{st}, \mu \mathrm{m}$ & $46.37 \pm 2.66^{\mathrm{a}}$ & $37.57 \pm 3.62^{\mathrm{b}}$ & $37.67 \pm 5.56^{\mathrm{b}}$ & $37.17 \pm 4.75^{\mathrm{b}}$ \\
$\mathrm{H}$ ad st, $\mu \mathrm{m}$ & $32.43 \pm 5.45^{\mathrm{a}}$ & $28.25 \pm 2.63^{\mathrm{ab}}$ & $24.31 \pm 5.90^{\mathrm{b}}$ & $24.14 \pm 2.68^{\mathrm{b}}$ \\
$\mathrm{N}$ ad st, N/mm ${ }^{2}$ & $19.47 \pm 8.56^{\mathrm{a}}$ & $18.44 \pm 7.99^{\mathrm{a}}$ & $14.34 \pm 4.9^{\mathrm{ab}}$ & $9.43 \pm 6.20^{\mathrm{b}}$ \\
$\mathrm{L}$ ab st, $\mu \mathrm{m}$ & $45.46 \pm 4.40^{\mathrm{a}}$ & $39.60 \pm 2.04^{\mathrm{b}}$ & $37.53 \pm 5.33^{\mathrm{b}}$ & $37.90 \pm 5.59^{\mathrm{b}}$ \\
$\mathrm{H}$ ab st, $\mu \mathrm{m}$ & $44.35 \pm 3.19^{\mathrm{a}}$ & $29.53 \pm 2.16^{\mathrm{b}}$ & $22.17 \pm 4.51^{\mathrm{c}}$ & $22.64 \pm 3.07^{\mathrm{c}}$ \\
$\mathrm{N}$ ab, N/mm ${ }^{2}$ & $10.37 \pm 5.90^{\mathrm{a}}$ & $12.68 \pm 6.90^{\mathrm{a}}$ & $4.15 \pm 5.3^{\mathrm{a}}$ & $3.32 \pm 4.10^{\mathrm{a}}$ \\
$\mathrm{S}$ ad ep, $\mu \mathrm{m}^{2}$ & $4855 \pm 1509^{\mathrm{a}}$ & $4302 \pm 685^{\mathrm{ab}}$ & $3312 \pm 686^{\mathrm{b}}$ & $3510 \pm 840^{\mathrm{b}}$ \\
$\mathrm{S}$ ab ep, $\mu \mathrm{m}^{2}$ & $6665 \pm 2470^{\mathrm{a}}$ & $6223 \pm 1230^{\mathrm{a}}$ & $2806 \pm 504^{\mathrm{b}}$ & $3910 \pm 1028^{\mathrm{b}}$ \\
\hline
\end{tabular}

Different letters indicate significant differences inside the parameters the same letters indicate no difference at $P<0.05$. $\mathrm{H}$ leaf - thickness of the leaf, $\mathrm{H}$ ad - thickness of the adaxial epidermis, $\mathrm{H}$ ad k - thickness of outer cell wall of the adaxial epidermis, $\mathrm{H} \mathrm{ab}$ - thickness of the abaxial epidermis, $\mathrm{H} \mathrm{ab} \mathrm{k}$ - thickness of outer cell wall of the abaxial epidermis, $\mathrm{L}$ ad st - length of a stomata of the adaxial epidermis, $\mathrm{H}$ ad st - width of a stomata of the adaxial epidermis, $\mathrm{N}$ ad st - number of stomata of the adaxial epidermis, $\mathrm{L}$ ab st - length of a stomata of the abaxial epidermis, $\mathrm{H}$ ab st - width of a stomata of the abaxial epidermis, $\mathrm{N}$ ab st - number of stomata of the abaxial epidermis, $\mathrm{S}$ ad ep - area of the adaxial epidermal cell, $\mathrm{S}$ ab ep - area of the abaxial epidermal cell.

C. perfoliata var. minor has got the thickest epidermis on the both leaf sides (essential epidermal cells were measured), compared to the other three species (Table 2). At the same time, there were no significant differences between the thicknesses of the outside cell wall of the epidermal cells. Additionally, the leaves of this species are covered in a layer of cells of epidermal origin with thick cell walls (Fig. 4, $A, B)$. The area cross-section of these cells makes $8702 \pm 771 \mu \mathrm{m}^{2}$ on the top side and $9444 \pm 1751 \mu \mathrm{m}^{2}$ on the underside of the leaf (Fig. 4, B).

Biochemical studies. Determination of lipid peroxidation level is important to understand how plants react to stress. MDA concentration depended on the species, temperature and the interaction between temperature and species (Table 3). Accumulation of MDA by C. muscosa and C. lanuliginosa at $40^{\circ} \mathrm{C}$ and by all species at $50{ }^{\circ} \mathrm{C}$ showed that the plants were stressed by rapid temperature increase. C. muscosa was the most stressed, whereas $C$. brevifolia - the least (Fig. 5, A). In addition, C. brevifolia and $C$. perfoliata var. minor showed activation of SOD when heated to $40^{\circ} \mathrm{C}$, which is one of the first antioxidant defense mechanisms in plants.
Five-time increase of SOD activity in $C$. perfoliata var. minor indicates the availability of a powerful defense mechanism through usage of this particular enzyme (Fig. 5, B). The increase in temperature to $50{ }^{\circ} \mathrm{C}$ increased SOD activity just in C. muscosa, whereas in other species SOD activity remained the same as in the control sample. SOD did not participate in antioxidant defense against hyperthermia in representatives of $C$. lanuliginosa. SOD activity was significantly affected by temperature, species and their interaction (Table 3).

Pigments content and peroxidase activity were significantly affected by temperature, species and their interaction (Table 3).

C. muscosa samples displayed an increase in peroxidase activity with slight increase in temperture, whereas when rapidly heated to $50{ }^{\circ} \mathrm{C}$, the plants showed no signs of its increase (Fig. 5, C). For C. lanuliginosa, peroxidase activity increased only at $50{ }^{\circ} \mathrm{C}$. A five-time increase of peroxidase activity for $C$. brevifolia plants both at $40{ }^{\circ} \mathrm{C}$ and $50{ }^{\circ} \mathrm{C}$ shows that the enzyme is the most engaged in antioxidant defense against hyperthermia for this species. Peroxidase activity in C. perfoliata var. minor 
$A$

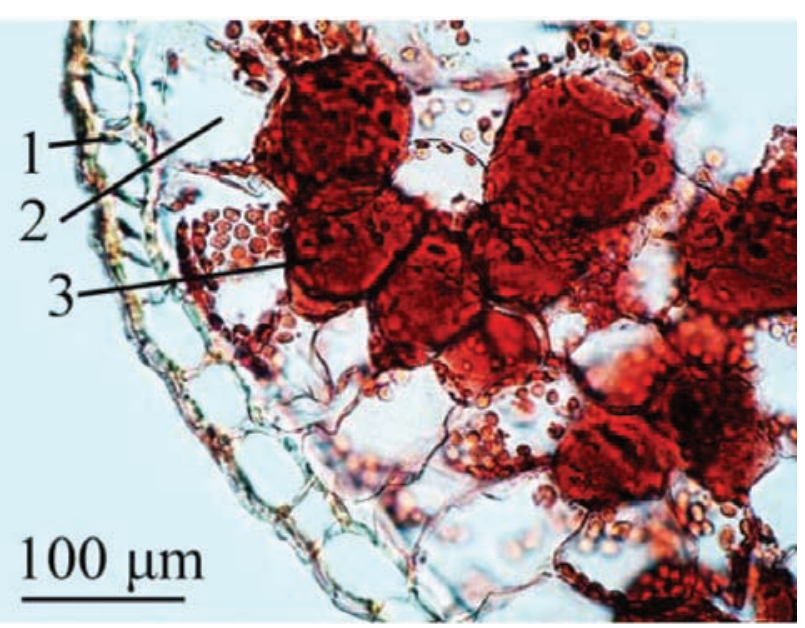

$B$

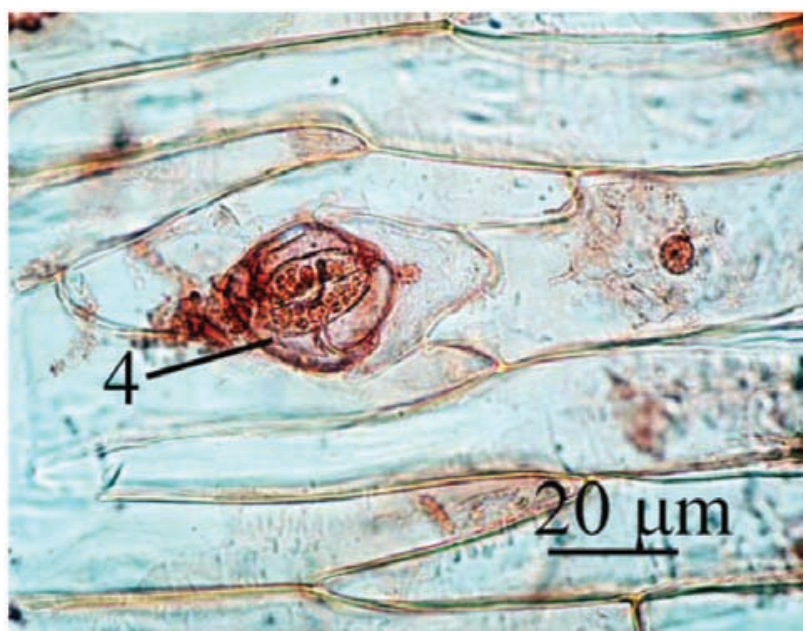

Fig. 1. Microscope photograph of C. muscosa leaf: A) leaf cross-section (dyed with safranin, sudan, I2-KI), B) abaxial leaf epidermis (dyed with safranin): 1 - adaxial epidermis, 2 - water-storage parenchyma; 3idioblasts; 4 - stomata

A

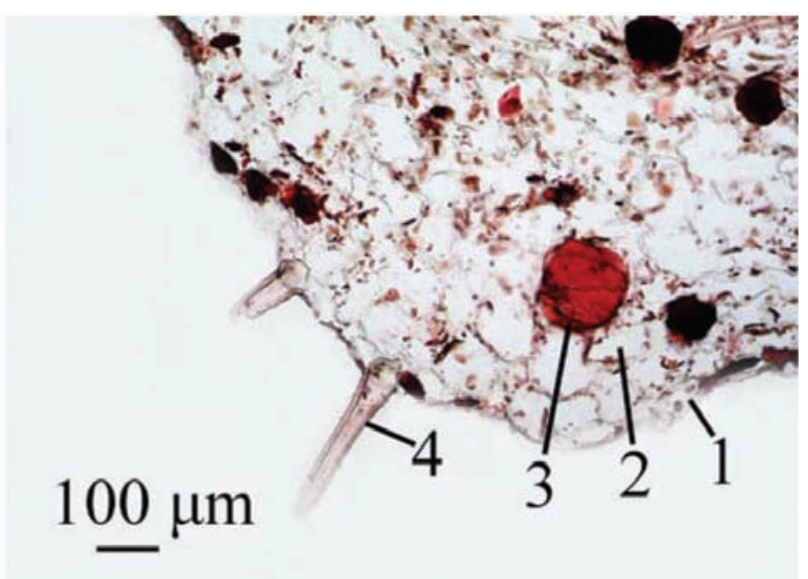

B

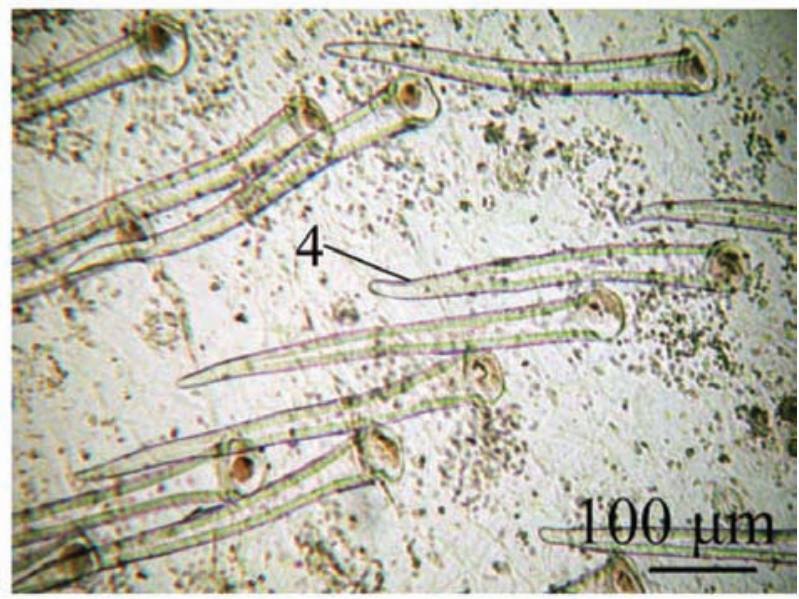

Fig. 2. Microscope photograph of C. lanuliginosa leaf: A) leaf cross-section (dyed with safranin, sudan, I2KI), B) abaxial leaf epidermis (dyed with safranin): 1 - adaxial epidermis, 2 - water- storage parenchyma; 3-idioblast; 4 - non glandular trichomes

did not change with temperature, although under the control conditions the species had a much higher activity of the enzyme compared to other species and a tendency for its decrease while the temperature rises to $50^{\circ} \mathrm{C}$. This may indicate a depletion of the available enzyme pool under stressful conditions.

Plants growing in high temperate regions are often exposed to stress. Photosynthesis is one of the metabolic processes most sensitive to high temperature stress, and it is often inhibited before other cellular functions [29]. According to the re- sults of our study, a short-term temperature increase had different effects on the pigment systems of the plants investigated. Namely, the amount of flavonoids rapidly increased at $50{ }^{\circ} \mathrm{C}$ in all species except C. perfoliata var. minor (Fig. 6, A). At the same time, no reliable change in flavonoid content was detected at $40{ }^{\circ} \mathrm{C}$. Only a small decrease of these substances was detected. It is worth mentioning that for control groups under no stress, flavonoid content in C. muscosa and $C$. perfoliata var. minor was twice more than in the other two species. 
A

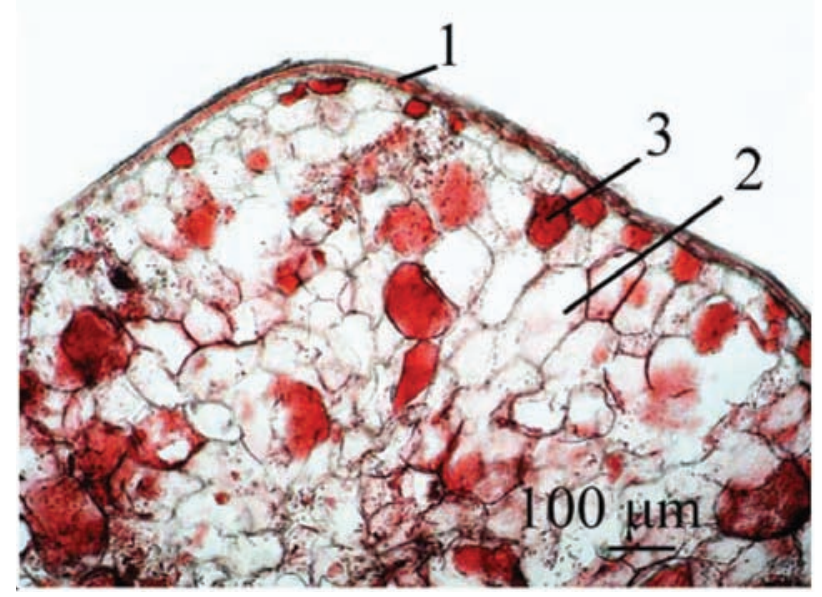

B

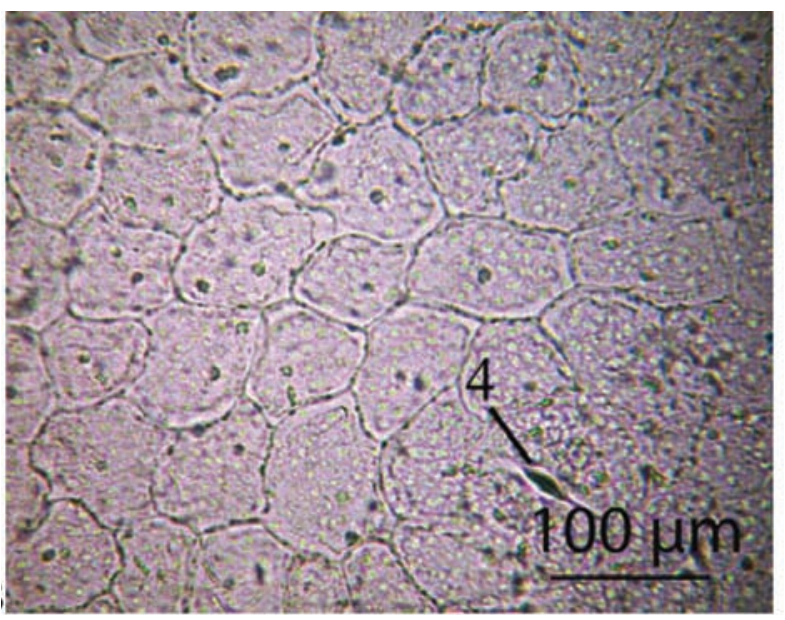

Fig. 3. Microscope photograph of C. brevifolia leaf: A) leaf cross-section (dyed with safranin, sudan, I2-KI), B) abaxial leaf epidermis (dyed with safranin): 1 - adaxial epidermis, 2 - water- storage parenchyma; 3-idioblast; 4 - stomata

A

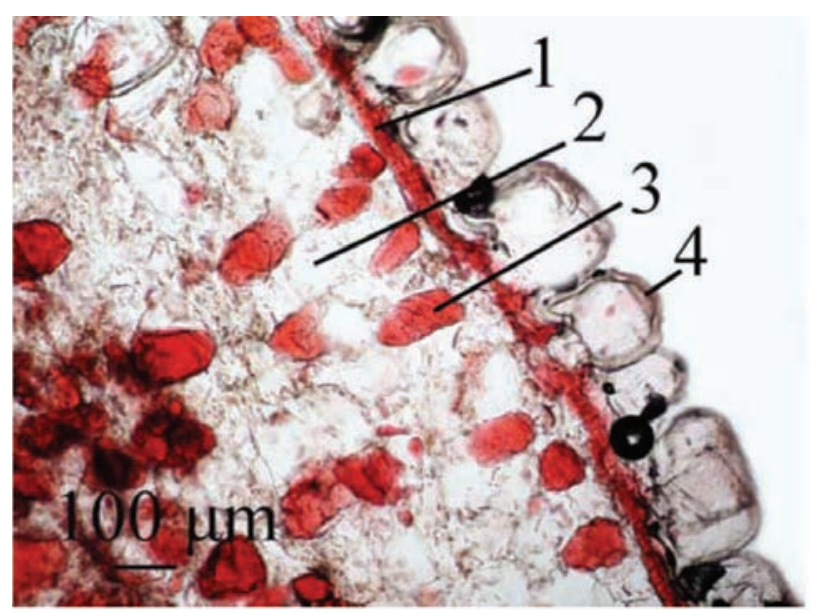

B

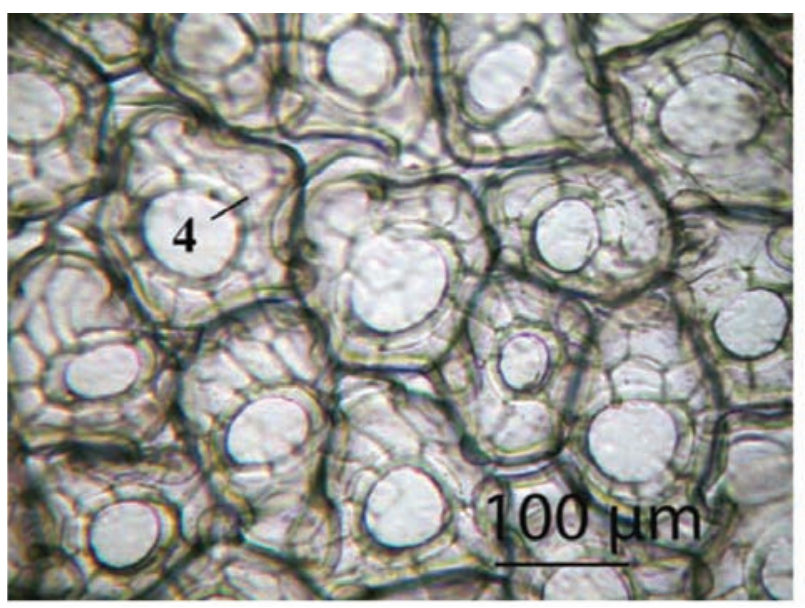

Fig. 4. Microscope photograph of C. perfoliata var.minor leaf: A) leaf cross-section (dyed with safranin, sudan, I2-KI), B) abaxial leaf epidermis (dyed with safranin): 1 - adaxial epidermis, 2 - water- storage parenchyma; 3-idioblast; 4 - cells of epidermal origin with thick cell walls

In control, leaves of $C$. brevifolia and $C$. perfoliata var. minor contain less chlorophyll of both types and carotinoids compared to the other two species (Fig. 6, B, C, D). For $C$. brevifolia, neither chlorophyll nor carotinoid content changed under temperature stress. For C. muscosa and C. perfoliata var. minor, chlorophyll $a$ and $b$ content increased when heated to $40{ }^{\circ} \mathrm{C}$, which was almost twice for C. perfoliata var. minor. Heating the plants to $50^{\circ} \mathrm{C}$ caused an increase of chlorophyll $a$ and $b$ content in C. muscosa and C. lanulaginosa, and a decrease in C. perfoliata var. minor. Hyperthermia has also affected the species differently when it comes to carotinoid contents. Indeed, an increase of carotinoid levels was detected at $50^{\circ} \mathrm{C}$ for $C$. muscosa and C. lanulaginosa; a decrease for $C$. lanulaginosa at $40^{\circ} \mathrm{C}$ and in C. perfoliata var. minor at $50^{\circ} \mathrm{C}$.

Chlorophyll $a$ to $b$ and chlorophylls to carotenoids ratios for $C$. brevifolia remained the same at both 40 and $50{ }^{\circ} \mathrm{C}$ (Fig. 6, E, F). Other three investigated species showed a reliable decrease of chlorophyll $a / b$ at $40^{\circ} \mathrm{C}$. Exposure to $50^{\circ} \mathrm{C}$ caused a decrease of the parameter related to control only in C. lanuliginosa, while no change was observed in 
A

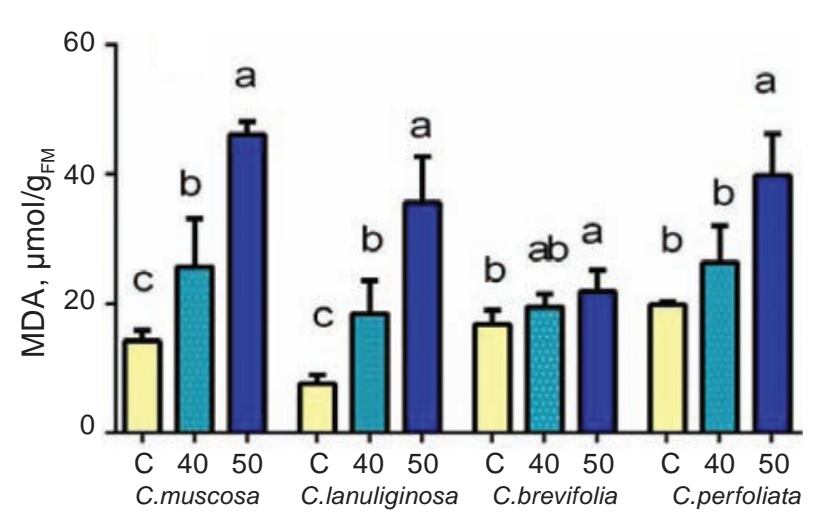

B

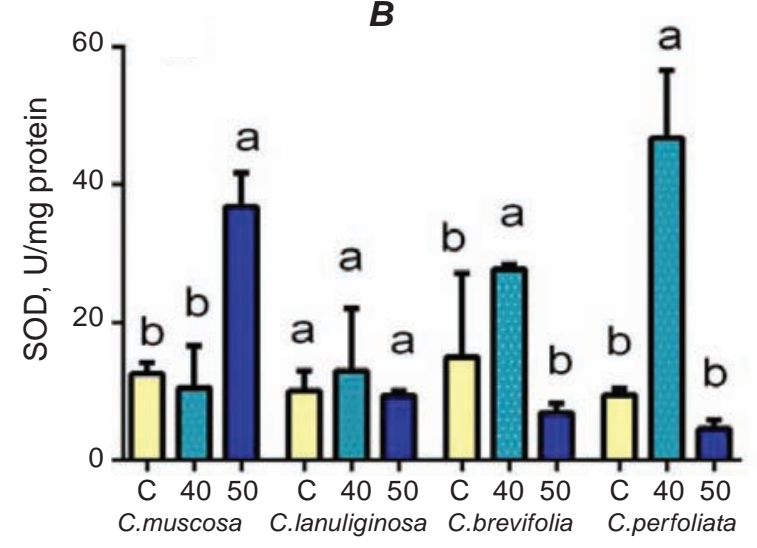

C

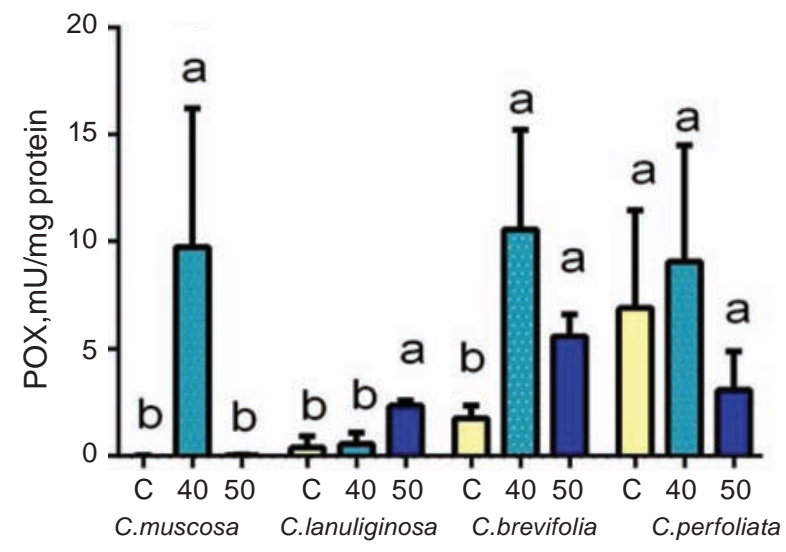

Fig.5. State of the antioxidant system and lipid peroxidation under hyperthermia. POX - peroxidase, FM fresh weight. Different letters indicate significant differences inside the parameters and species the same letters indicate no difference at $P<0.05$

the other species. At the same time, when the plants were exposed to $50{ }^{\circ} \mathrm{C}$, the amounts of both chlorophyll types increased more evenly.

Just as in the previous results, hyperthermia did not influence the chlorophylls/carotenoids ratio for $C$. brevifolia. For the other species, less intensive heating caused an increase of the ratio, while short-term exposure to $50{ }^{\circ} \mathrm{C}$ didn't affect it. Thus, only chlorophylls concentration increased at $40{ }^{\circ} \mathrm{C}$ whereas content both chlorophylls and carotenoids increased at $50{ }^{\circ} \mathrm{C}$.

For better understanding adaptive strategies we analyzed changes of biochemical parameters under conditions of abrupt hyperthermia in four species of Crassula L. genus and their anatomical features.

C. brevifolia plants have distinguished xeromorphous features: the thickest leaf with well-developed water-conducting parenchyma, the smallest epidermocytes with a lignified outer cell wall and a thick cuticle. The latter indicators, in addition to increasing drought resistance, also increase the heat resistance of the plant. Such resilience is also confirmed by data coming from our research across the years, namely: long-term (week-long) increase of the greenhouse temperature to $50{ }^{\circ} \mathrm{C}$ does not impact significantly growth and development of $C$. brevifolia. Also, C. brevifolia was the most resilient to sharp temperature changes on the biochemical level, which manifested in weak increase of lipid peroxidation, activation of powerful antioxidant protection mechanisms represented by SOD, peroxidase and flavonoids and in the stability of the photosynthetic system. Increase of SOD and peroxidase activity under lesser stress $\left(40^{\circ} \mathrm{C}\right)$ occurs, first and foremost, due to activation of existing enzymes, which was confirmed by our researchers $[14,30]$. At the same time, according to literature data, a more intensive stress caused a faster and stronger activation of available antioxidant enzymes during the first several hours, more intensive usage of the enzyme pool for neutralizing of the formed free radicals, after which a decrease in activity was observed 
Table 3. Two-way ANOVA of the parameters measured in plants of Crassula brevifolia, C. lanuliginosa, C. muscosa and C. perfoliata var. minor, exposed to heat stress at temperatures of $40^{\circ} \mathrm{C}$ and $26{ }^{\circ} \mathrm{C}$ in control group

\begin{tabular}{|c|c|c|}
\hline Source & F (DFn, DFd) & $P$ value \\
\hline \multicolumn{3}{|c|}{ Malone dialdehyde } \\
\hline Temperature & $\mathrm{F}(2,48)=118.8$ & $P<0.0001^{*}$ \\
\hline Species & $F(3,48)=19.70$ & $P<0.0001^{*}$ \\
\hline Interaction & $F(6,48)=9.446$ & $P<0.0001^{*}$ \\
\hline \multicolumn{3}{|c|}{ Superoxide dismutase } \\
\hline Temperature & $F(2,44)=28.44$ & $P<0.0001^{*}$ \\
\hline Species & $F(3,44)=8.874$ & $P=0.0001^{*}$ \\
\hline Interaction & $F(6,44)=34.80$ & $P<0.0001^{*}$ \\
\hline \multicolumn{3}{|c|}{ Peroxidase } \\
\hline Temperature & $F(2,44)=4.767$ & $P=0.0134 *$ \\
\hline Species & $F(3,44)=22.18$ & $P<0.0001^{*}$ \\
\hline Interaction & $F(6,44)=4.064$ & $P=0.0025^{*}$ \\
\hline \multicolumn{3}{|c|}{ Flavonoids } \\
\hline Temperature & $F(2,48)=37.23$ & $P<0.0001^{*}$ \\
\hline Species & $F(3,48)=5.989$ & $P=0.0015^{*}$ \\
\hline Interaction & $F(6,48)=6.980$ & $P<0.0001^{*}$ \\
\hline \multicolumn{3}{|c|}{ Protein } \\
\hline Temperature & $\mathrm{F}(2,48)=38.27$ & $P<0,0001^{*}$ \\
\hline Species & $\mathrm{F}(3,48)=43.50$ & $P<0.0001^{*}$ \\
\hline Interaction & $F(6,48)=26,03$ & $P<0.0001^{*}$ \\
\hline \multicolumn{3}{|c|}{ Chlorophyll a } \\
\hline Temperature & $F(2,48)=27.77$ & $P<0.0001^{*}$ \\
\hline Species & $F(3,48)=291.2$ & $P<0.0001^{*}$ \\
\hline Interaction & $F(6,48)=61.31$ & $P<0.0001^{*}$ \\
\hline \multicolumn{3}{|c|}{ Chlorophyll b } \\
\hline Temperature & $F(2,48)=36.48$ & $P<0.0001 *$ \\
\hline Species & $F(3,48)=85.81$ & $P<0.0001^{*}$ \\
\hline Interaction & $F(6,48)=26.88$ & $P<0.0001^{*}$ \\
\hline \multicolumn{3}{|c|}{ Carotenoids } \\
\hline Temperature & $F(2,48)=20.05$ & $P<0.0001^{*}$ \\
\hline Species & $F(3,48)=147.7$ & $P<0.0001^{*}$ \\
\hline Interaction & $F(6,48)=30.38$ & $P<0.0001^{*}$ \\
\hline
\end{tabular}

*Significant differences within one of three variables temperature, species, or their interactions.
[30-32]. Since MDA level at $50^{\circ} \mathrm{C}$ was the lowest in C. brevifolia, compared to other species, the lower SOD activity level at $50^{\circ} \mathrm{C}$ compared to $40^{\circ} \mathrm{C}$ might be explained as faster depletion of available enzymes for antioxidant needs, which might be an indication of efficient performance of the antioxidant system at this level. Increase of peroxidase activity in response to high temperature treatment was also confirmed by other researchers [33, 34]. At the same time, other species displayed somewhat different results as for the role of peroxidase in the antioxidant response to high temperature: peroxidase activity increased or stayed the same for rhododendrons and haworthias [15]; activity increased, decreased or stayed the same $[16,34]$.

Anatomical structure studies has shown that representatives of $C$. perfoliata var. minor are the most xerophytous by such features as: the thickest epidermis, small epidermal cells, the smallest amount of stomata, a thick leaf with well-developed water-conducting parenchyma, presence of transformed epidermal air-conducting cells with thick cell walls, which comprise an additional full layer by connecting of apical cell parts. Such air-filled cells may also effectively protect the plant internal structures from overheating. Such anatomical protection helps plants withstand a sharp rise in temperature by reducing the stress influence on internal leaf structures. In addition, these plants effective controlled the oxidative stress by the antioxidant system under hyperthermia. C. perfoliata var. minor plants had an absence of lipid peroxidation at $40{ }^{\circ} \mathrm{C}$. This fact was influenced by very high SOD at $40{ }^{\circ} \mathrm{C}$ (like to C. brevifolia) and peroxidase activity under control conditions; also, an increase of chlorophyll $a$ and $b$ amounts at $40{ }^{\circ} \mathrm{C}$ was noted. However, at $50{ }^{\circ} \mathrm{C}$, disruption of the pigments of the photosynthetic systems was observed in $C$. perfoliata var. minor plants: chlorophyll $a$ and $b$ amounts are halved in comparison with the control sample. Therefore it can be stated that rapid increase of the temperature to $40{ }^{\circ} \mathrm{C}$ does not affect the photosynthetic system of the studied species negatively, whereas $50{ }^{\circ} \mathrm{C}$ is destructive for the said system of C. perfoliata var. minor. The pigment system of this particular species proved to be the least resistant to intensive hyperthermia $\left(50^{\circ} \mathrm{C}\right)$. According to litera- 

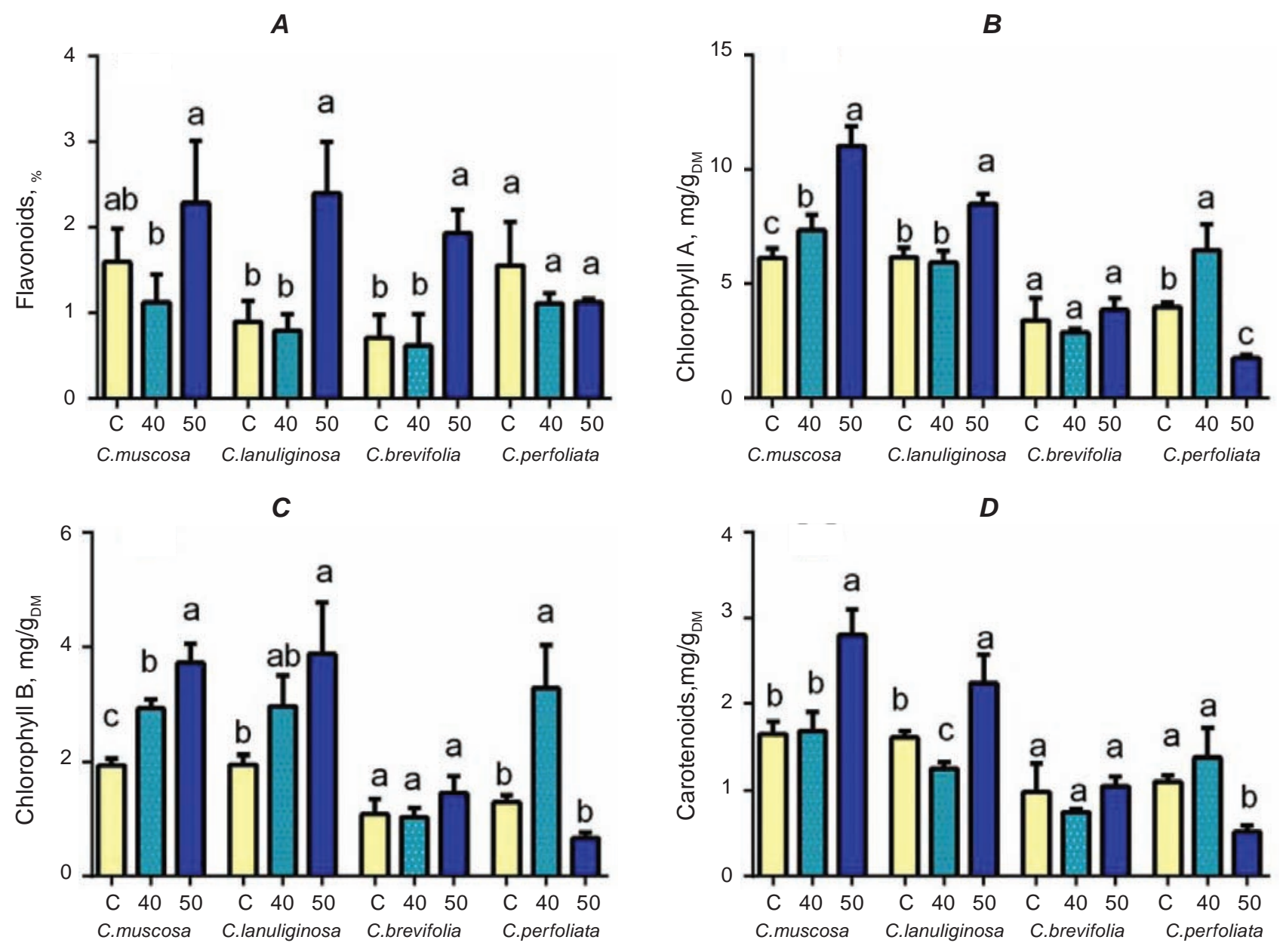

$E$
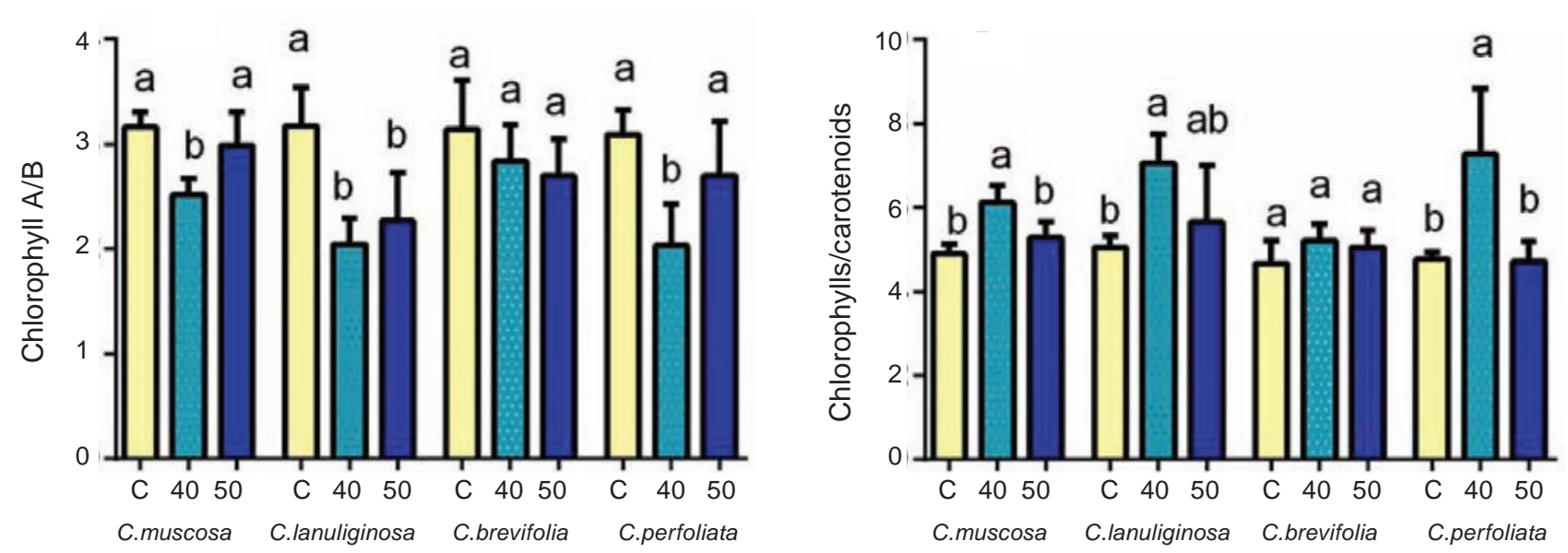

Fig. 6. Indicators of pigment complex before and after exposure to high temperature. Different letters indicate significant differences inside the parameters and species the same letters indicate no difference at $P<0.05$

ture sources, negative effect of high temperature on the photosynthesis-involved pigments is more common, especially in case of long-term exposure [29, 35, 36]. At the same time, our results from studying the Crassula genus representatives as well as other species [15-17] show varied influence of short-term hyperthermia, even among representatives the same genus: one species might have an increase of chlorophyll and carotenoid amounts as a stress response (for example C. muscosa), while in another the said 
amounts stay stable (for example in C. brevifolia) or decrease of pigments numbers (C. perfoliata var. minor at $50^{\circ} \mathrm{C}$ ). In our opinion, such differences might primarily depend on the anatomical structure of the species. At the same time, $C$. perfoliata var. minor plants can endure longstanding exposure to high temperature in greenhouse conditions during summer, which can be explained by adaptation of the photosynthetic system to such conditions.

At the same time, the least xerophyte features were found in representatives of $C$. muscosa. C. muscosa has no additional protection on the epidermal level, unlike the other three species. It has the largest stomata and epidermal cells, a larger number of stomata, which cool the plant by more intense transpiration at the first stades of heating. On the other hand, C. muscosa leaves stick closely together, ensuring protection for the bottom leaves by the top ones, which also can improves its heat resistance. Absence an additional epidermal protection may be accompanied by the stress influence of high temperature on internal leaf structures. Similar results were observed on haworthias and representatives of the Cactaceae family [15, 16, 37] and rhododendrons, where the least heat-resistant species were those which had the thinnest leaves, thinner outside cell walls and larger epidermal cell surface areas [38]. In C. muscosa, hyperthermia caused stress already at $40{ }^{\circ} \mathrm{C}$, and at $50^{\circ} \mathrm{C}$ the MDA content was tripled. With less intensive heating, peroxidase was activated and chlorophyll $a$ and $b$ contents increased. Decrease of value chlorophyll $a / b$ at $40{ }^{\circ} \mathrm{C}$ for this and other species (exept $C$. brevifolia) is caused by a more intensive synthesis of chlorophyll $b$ than chlorophyll $a$ under light temperature stress. However, at $50^{\circ} \mathrm{C}$, the species had its SOD (activity tripling), carotenoid and chlorophyll protective mechanisms enabled. The level of constitutive peroxidase activity in C. muscosa is very low. This might be the reason why peroxidase doesn't take part in the antioxidant reaction under intensive high-temperature influence in this species (as opposed to C. brevifolia and C. perfoliata var. minor). On the anatomical level, C. muscosa is also worse protected, and therefore more MDA is accumulated in comparison to C. brevifolia and C. perfoliata var. minor; as a consequence, it is possible that under intensive temperature stress $\left(50^{\circ} \mathrm{C}\right)$, additional protective measures, such as synthesis of additional SOD, flavonoids, carotenoids and chlorophylls are enabled. Compensatory interactions of different antioxidants are also described in studies by other researchers, namely - when some antioxidant enzymes are suppressed, others activate [39]; decrease of peroxidase activity is accompanied by extra carotinoid synthesis [40]. According to literature data, the increase of hyper- or hypothermia causes a uniform decrease of SOD activity in many plant species [15, 16, 41]. Some researchers studied multidirectional reaction SOD on heat stress in plants of different species, indicating different ways to adapt $[34,42,43]$. Thus, our research has confirmed the species-dependant (Table 3) SOD reaction to hightemperature stress $[15,16]$.

A specific distinction of the succulent leaves of C. lanuliginosa is the presence of simple single-cell trichomes on the both sides. However, such pubescence is not dense enough to provide intense protection against heat. At the same time, these plants have the mechanism of overheating protection by increasing transpiration and cool the plant (they have the largest epidermal cells, a larger number of stomata). However, such a mechanism turned out not effective enough against short-term high temperature action. C. lanuliginosa showed a two-fold increase in MDA level at $40^{\circ} \mathrm{C}$ and a five-time increase at $50{ }^{\circ} \mathrm{C}$, which is the highest stress level among the studied species. Also, its antioxidant protection was insignificant. Indeed, protective mechanisms only started working $50{ }^{\circ} \mathrm{C}$ : peroxidase activity was scarce and increased five times with heating, but the activity was very low compared to that of other species; flavonoid, chlorophyll and carotenoid amounts increase. It can be explained by involving of additional protective mechanisms by plants with weak protection from high temperature at the anatomical level, similar to C. muscosa. The acquired results of flavonoid reaction to temperature stress are confirmed in literature: indeed, flavonoid content increased or stayed the same, had different reaction in different genera of the Cactaceae family [16], decreased [15, 44]. Lower resistance to hyperthermia of C. lanuliginosa and C. muscosa is also confirmed by many years of observation during introduction. Namely, week-long exposure to high temperature $\left(50^{\circ} \mathrm{C}\right.$ ) caused burnt leaf edges in C. muscosa and decreased growth rate in $C$. lanuliginosa. We did not detect any influence of short-term hyperthermia on growth and development of the investigated species: within a month after exposure to heat plants of all studied species showed morphometric characteristics similar to the control plants.

In conclusion, in can be stated, that antioxidant response to short-term temperature impact varies 
from species to species as well as for different genera by its direction and intensity and depends on the anatomical structure of the plant. Having analyzed the results from studying the species of the Crassula genus and also other species from our previous studies as well as literature data, we have discovered distinct trends. C. perfoliata var. minor and C. brevifolia, having the most xerophyte features among the four species, which additionally protect against the effects of high temperature (thicker leaf blades (improved water-storing tissue), thicker epidermis, smaller epidermal cells), showed better heat-resistance than the other two species of this genus. More effective protection at the anatomical level and a powerful antioxidant protection under rapid heating are accompanied by a smaller increase in the lipid peroxidation level due to stress. Moreover, thickened leaf and epidermis may contribute to the partial avoidance of lipid peroxidation. C. lanuliginosa and C. muscosa plants are less heat-resistant among the studied species. The weak protection from high temperature at the anatomical level (thinner leaf blades and epidermis, larger epidermal cells and number of stomata) and an insufficient activity of SOD and peroxidase in $C$. lanuliginosa were accompanied by a greater accumulation of MDA due to hyperthermia. On the other hand, additional protective mechanisms were involved in these plants, such as increased carotenoids, chlorophylls and flavonoids contents.

Conflict of interest. Authors have completed the Unified Conflicts of Interest form at http:// ukrbiochemjournal.org/wp-content/uploads/2018/12/ coi_disclosure.pdf and declare no conflict of interest.

Acknowledgements. Experiments were partially supported by of the grant from Taras Shevchenko National University of Kyiv No 18BP036-05.

\section{ВІДПОВІДЬ РОСЛИН РОДУ Crassula НА ТЕМПЕРАТУРНИЙ СТРЕС ЗАЛЕЖИТЬ ВІД АНАТОМІЧНОЇ СТРУКТУРИ І АНТИОКСИДАНТНОЇ СИСТЕМИ}

\author{
Н. В. Нужина ${ }^{\bowtie}$, М. М. Гайдаржи, \\ А. В. Голубенко
}
ННЦ «Інститут біології та медицини», Київський національний університет імені Тараса Шевченка, Україна;
凶e-mail: nuzhynan@gmail.com

Одним із найважливіших факторів, які забезпечують виживання рослин, є стійкість до високої температури навколишнього середовища, що залежить від біохімічної системи захисту рослин, а також від їхніх структурних особливостей. Метою роботи було оцінити показники антиоксидантної системи та анатомо-морфологічні особливості чотирьох видів роду Crassula Linne в умовах різкої гіпертермії. Рослини Crassula brevifolia Harvey, Crassula lanuliginosa Harvey, Crassula muscosa Linne and Crassula perfoliata var. minor (Haworth) G. D. Rowley тримали в повітряних термостатах при $40{ }^{\circ} \mathrm{C}$ та 50 ${ }^{\circ} \mathrm{C}$ протягом 3 год, температура контролю була $26{ }^{\circ} \mathrm{C}$. Відповідь на стрес оцінювали за активністю супероксиддисмутази і пероксидази, активними продуктами ТБК та вмістом пігментів. Показано, що антиоксидантна реакція на короткочасну високу температуру відрізняється в різних видів роду Crassula і залежить від анатомічних особливостей рослин. Підвищену активність СОД та пероксидази спостерігали в рослин із ефективнішим захистом на анатомічному рівні. У менш жаростійких рослин внаслідок гіпертермії були залучені додаткові захисні механізми, такі як підвищення вмісту каротиноїдів і флавоноїдів.

К л ю ч о в і с ло ва: гіпертермія, пероксидаза, супероксиддисмутаза, пігменти, рід Crassula. 


\section{References}

1. Lamaoui M, Jemo M, Datla R, Bekkaoui F. Heat and drought stresses in crops and approaches for their mitigation. Front Chem. 2018; 6: 26.

2. Suzuki N, Mittler R. Reactive oxygen species and temperature stresses: A delicate balance between signaling and destruction. Physiologia Plantarum. 2006; 126(1): 45-51.

3. Shao HB, Chu LY, Shao MA, Jaleel CA, Mi HM. Higher plant antioxidants and redox signaling under environmental stresses. C R Biol. 2008; 331(6): 433-441.

4. Kolupaev YuE. Antioxidants of plant cell, their role in ROS signaling and plant resistance. Usp Sovrem Biol. 2016; 136(2): 181-198. (In Russian).

5. Kolupaev YuE, Karpets YuV, Kabashnikova LF. Antioxidative System of Plants: Cellular Compartmentalization, Protective and Signaling Functions, Mechanisms of Regulation (Review). Appl Biochem Microbiol. 2019; 55(5): 441-459.

6. Gill SS, Tuteja N. Reactive oxygen species and antioxidant machinery in abiotic stress tolerance in crop plants. Plant Physiol Biochem. 2010; 48(12): 909-930.

7. Vahdati K, Leslie Ch. (Ed.) Abiotic Stress - Plant Responses and Applications in Agriculture. Croatia: Intech, 2013. 410 p.

8. Hussain HA, Men Sh, Hussain S, Chen Y, Ali Sh, Zhang S, Zhang K, Li Y, Xu Q, Liao Ch, Wang L. Interactive effects of drought and heat stresses on morpho-physiological attributes, yield, nutrient uptake and oxidative status in maize hybrids. Sci Rep. 2019; 9(1): 3890.

9. Hirayama T, Shinozaki K. Research on plant abiotic stress responses in the post-genome era: past, present and future. Plant J. 2010; 61(6): 1041-1052.

10. Van Jaarsveld E. Crassula. In Illustrated Handbook of Succulent Plants: Crassulaceae. Berlin: Springer, 2003. P.32-84.

11. Woith E, Stintzing F, Melzig MF. SOD activity and extremophilicity: a screening of various plant species. Pharmazie. 2017; 72(8): 490-496.

12. Carvalho K, de Campos MKF, Domingues DS, Pereira LFP, Vieira LGE. The accumulation of endogenous proline induces changes in gene expression of several antioxidant enzymes in leaves of transgenic Swingle citrumelo. Mol Biol Rep. 2013; 40(4): 3269-3279.
13. Khan H, Shah SH, Uddin N, Azhar N, Asim M, Syed S, Ullah F, Tawab F, Inayat J. Biochemical and physiological changes of different plants species in response to heat and cold stress. ARPN J Agric Biol Sci. 2015; 10(6): 213-216.

14. Ardelean M, Cachita-Cosma D, Ardelean A, Ladasius C, Mihali VC. The effect of heat stress on hyperhydricity and guaiacol peroxidase activity (GPOX) at the foliar lamina of Sedum telephium L. ssp. maximum (L.) Krock. Vitroplantlets. Analele Stiint Univ Al I Cuza Iasi, Sect. II a. Biol veget. 2014; 60(2): 21-31.

15. Nuzhyna NV, Gaidarzhy MM, Aviekin YaV. Species-specific response to acute hypertermal stress of Haworthia (Asphodelaceae) plants. Regul Mech Biosyst. 2017; 8(4): 506-511. (In Ukrainian).

16. Nuzhyna N, Baglay K, Golubenko A, Lushchak O. Anatomically distinct representatives of Cactaceae Juss. family have different response to acute heat shock stress. Flora. 2018; 242: 137145.

17. Nuzhyna NV, Tkachuk OO. Various antioxidant responses to hyperthermia in anatomically different species of the genus Rosa. Biosyst Divers. 2019; 27(3): 193-199.

18. Rowley G. Crassula: a grower's guide. London, Cactus\&Co, 2008. 247 p.

19. Red List of South African Plants. Pretoria: Strelitzia 25, 2009. 668 p.

20. Ruzin SE. Plant microtechnique and microscopy. UK: Oxford University Press, 1999. 322 p.

21. Zarinkamar F. Stomatal observations in dicotyledons. Pak J Biol Sci. 2007; 10(2): 199-219.

22. Kumar GNM, Knowles NR. Changes in lipid peroxidation and lipolitic and free radical scavenging enzyme activities during aging and sprouting of potato (Solanum tuberosum) seedtubers. Plant Physiol. 1993; 102(1): 115-124.

23. Giannopolitis CN, Ries SK. Superoxide dismutase I. Occurrence in higher plants. Plant Physiol. 1977; 59(2): 309-314.

24. Warburg O, Christian W. Isolierung und Kristallisation des Garungsferments Enolase. Biochem Z. 1941; 310: 384-421.

25. Sharifi G, Ebrahimzadeh H. Changes of antioxidant enzyme activities and isoenzyme profiles during in vitro shoot formation in saffron (Crocus sativus L.). Acta Biol Hung. 2010; 61(1): 73-89. 
26. Payum T, Das AK, Shakar R, Tamuly C, Hazarika M. Antioxidant potential of Solanum spirale shoot and berry: a medicinal food plant used in arunachal pradesh. Am J PharmTech Res. 2015; 5(4): 307-314.

27. Lichtenthaller HK. Chlorophylls and carotenoids, pigments of photosynthetic biomembranes. Methods Enzymol. 1987; 148: 350-382.

28. Karwowska K, Brzezicka E, KozieradzkaKiszkurno M, Chernetskyy M. Anatomical structure of the leaves of Crassula cordata (Crassulaceae). Mod Phytomorphol. 2015; 8: 5354.

29. Chen WR, Zheng JS, Li YQ, Guo WD. Effects of high temperature on photosynthesis, chlorophyll fluorescence, chloroplast ultrastructure, and antioxidant activities in fingered citron. Russ $J$ Plant Physiol. 2012; 59(6): 732-740.

30. Ignatenko AA, Repkina NS, Titov AF, Talanova VV. The response of cucumber plants to low temperature impacts of varying intensity. Proc Karelian Sci Center RAS. 2016; (11): 57-67.

31. Feng Zh, Guo A, Feng Z. Amelioration of chilling stress by triadimefon in cucumber seedlings. Plant Growth Regul. 2003; 39: 277-283.

32. Junmatong C, Faiyue B, Rotarayanont S, Uthaibutraa J, Boonyakiat D, Saengnil K. Cold storage in salicylic acid increases enzymatic and non-enzymatic antioxidants of Nam Dok Mai No. 4 mango fruit. Sci Asia. 2015; 41(1): 12-21.

33. Gulen H, Eris A. Effect of heat stress on peroxidase activity and total protein content in strawberry plants. Plant Sci. 2004; 166(3): 739744.

34. He Y, Huang B. Differential responses to heat stress in activities and isozymes of four antioxidant enzymes for two cultivars of kentucky bluegrass contrasting in heat tolerance. J Am Soc Hortic Sci. 2010; 135(2): 116-124.

35. Zhang X, Wang K, Ervin EH. Optimizing dosages of seaweed extract-based cytokinins and zeatin riboside for improving creeping bentgrass heat tolerance. Crop Sci. 2010; 50(1): 316-320.
36. Ashraf M, Harris PJC. Photosynthesis under stressful environments: An overview. Photosynthetica. 2013; 51(2): 163-190.

37. Nuzhyna NV, Gaydarzhy MN. Comparative characteristics of anatomical and morphological adaptations of plants of two subgenera Haworthia Duval to arid environmental conditions. Acta Agrobot. 2015; 68(1): 23-31.

38. Nuzhyna NV, Kondratiuk-Stoyan VV. The features of leaf anatomical structure of some Rhododendron species from section Ponticum. Mod Phytomorphol. 2017; 11: 21-27.

39. Palatnik JF, Valle EM, Federico ML, Gómez LD, Melchiorre MN, Paleo AD, Carrillo N, Acevedo A. Status of antioxidant metabolites and enzymes in a catalase-deficient mutant of barley (Hordeum vulgare L.). Plant Sci. 2002; 162(3): 363-371.

40. Chang CCC, Slesak I, Jorda L, Sotnikov A, Melzer M, Miszalski Z, Mullineaux PM, Parker JE, Karpińska B, Karpiński St. Arabidopsis chloroplastic glutathione peroxidases play a role in cross talk between photooxidative stress and immune responses. Plant Physiol. 2009; 150(2): 670-683.

41. Zhang J, Kirkham MB. Drought-stress induced changes in activities of superoxide dismutase, catalase and peroxidases in wheat leaves. Plant Cell Physiol. 1994; 35(5): 785-791.

42. Panda SK, Khan MH. Changes in growth and superoxide dismutase activity in Hydrilla verticillata L. under abiotic stress. Braz J Plant Physiol. 2004; 16(2): 115-118.

43. Harsha A, Sharmaa YK, Joshia U, Rampuriaa S, Singha G, Kumarb S, Sharma R. Effect of shortterm heat stress on total sugars, proline and some antioxidant enzymes in moth bean (Vigna aconitifolia). Ann Agric Sci. 2016; 61(1): 57-64.

44. Mori K, Goto-Yamamoto N, Kitayama M, Hashizume K. Loss of anthocyanins in red-wine grape under high temperature. J Exp Bot. 2007; 58(8): 1935-1945. 